Article

\title{
Effect of Climate Change on Soil Erosion in a Mountainous Mediterranean Catchment (Central Pindus, Greece)
}

\author{
Stefanos Stefanidis * and Dimitrios Stathis \\ Laboratory of Mountainous Water Management and Control, Faculty of Forestry and Natural Environment, \\ Aristotle University of Thessaloniki, 54124 Thessaloniki, Greece; dstatis@for.auth.gr \\ * Correspondence: ststefanid@gmail.com; Tel.: +30-2310-992712
}

Received: 24 September 2018; Accepted: 16 October 2018; Published: 18 October 2018

check for updates

\begin{abstract}
The aim of this study was to assess soil erosion changes in the mountainous catchment of the Portaikos torrent (Central Greece) under climate change. To this end, precipitation and temperature data were derived from a high-resolution $(25 \times 25 \mathrm{~km})$ RegCM3 regional climate model for the baseline period 1974-2000 and future period 2074-2100. Additionally, three GIS layers were generated regarding land cover, geology, and slopes in the study area, whereas erosion state was recognized after field observations. Subsequently, the erosion potential model (EPM) was applied to quantify the effects of precipitation and temperature changes on soil erosion. The results showed a decrease $(-21.2 \%)$ in annual precipitation $(\mathrm{mm})$ and increase $\left(+3.6^{\circ} \mathrm{C}\right)$ in mean annual temperature until the end of the 21 st century, and the above changes are likely to lead to a small decrease $(-4.9 \%)$ in soil erosion potential.
\end{abstract}

Keywords: erosion; Gavrilovič; climate change; RCMs; mountainous catchment

\section{Introduction}

Climatologists highlight that climate change is occurring, both in terms of air temperature and precipitation patterns. According to the Intergovernmental Panel on Climate Change's (IPCC) Fifth Assessment Report, the Mediterranean basin is expected to become warmer and dryer due to an anthropogenic increase of greenhouse gas emissions $\left(\mathrm{CO}_{2}, \mathrm{CH}_{4}, \mathrm{~N}_{2} \mathrm{O}\right.$, and F-gases) until the end of the 21st century [1]. Moreover, in Mediterranean regions, future warming will probably be larger than the global mean, accompanied by a considerable decrease of total rainfall amount [2,3] and more frequent high-intensity rainfall events $[4,5]$. Future climate projections will highly influence catchments' responses to soil erosion [6-9].

Soil erosion by water is one of the most significant forms of land degradation, as it threatens natural ecosystems, water resources, and crop productivity. The European Commission's Soil Thematic Strategy has identified soil erosion as a key priority for the protection of soils [10] and call for quantitative assessments of soil loss rates at the European level [11]. Mediterranean regions are particularly vulnerable to erosion because of the highly irregular behavior of the rainfall regime, both on spatial and temporal scales [12]; inappropriate agricultural management practices [13]; overgrazing [14,15]; and wildfires [16,17]. Also, erosion rates are higher in mountainous areas than in lowlands due to the steeper relief and the higher and more intense rainfalls.

Identification of critical soil erosion-prone areas is necessary for the implementation of appropriate mitigation measures to combat erosion [18-20]. Stakeholders should also quantify potential soil erosion risk under future climate conditions for the scheduling of infrastructure projects.

Actual measurements of soil erosion rates is a costly and time-consuming process that is usually limited to small experimental sites [21-25].To this end, plenty of erosion prediction models were 
developed during the last few decades and classified on different spatial/temporal scales and various levels of complexity [26].Erosion prediction models use mathematical equations so as to express the relationships between natural factors (e.g., rainfall, land cover, vegetation type, geological subsoil, and topography) and the erosion process. The most well-known models that have been widely used are USLE [27], RUSLE [28], RMMF [29], WEPP [30], and EPM (the Gavrilovič method) [31].

The quantitative erosion prediction model of Gavrilovič was developed using field work and laboratory experiments to determine the range of values for its parameters. It was widely used in former Yugoslavia since the early 70s, and later in the Balkan region and Central Europe. It has also been recognized as the most quantitative of all the semi-quantitative models [32]. Several studies in the mountainous catchments of Greek territory which compare the Gavrilovič prediction model results with actual measurements shows that it gives satisfactory results [33-36].

In recent years, climate models' projections have been used to assess soil erosion under climate change $[37,38]$. Understanding the uncertainties of several climatological parameters is of major interest in recent climate studies [39]. It should be noted that the ability of models to represent climate conditions should be examined prior to their use in impact assessment studies [40-43].

Investigation of the effects of climate change on soil erosion using high-resolution Regional Climate Models (RCMs) are limited in mountainous catchments of the Mediterranean region [44], while no such research has been carried out in Greece.

The main object of the current research is to quantify the effect of climate change on soil erosion in a mountainous catchment of Central Greece using the erosion prediction model of Gavrilovič and climate simulation of the RegCM3regional climate model.

\section{Materials and Methods}

\subsection{Study Area}

The study was conducted in the mountainous catchment of the Portaikos torrent (Figure 1). It is located in the Thessaly Regional Unit (Central Greece) over the mountain range of Pindus, and is a tributary of the Pinios River. It covers an area of $136.4 \mathrm{~km}^{2}$ and the relief is rather intense. The mean elevation is 963 meters above sea level (MASL) (maximum 1862 MASL and minimum 240 MASL), whereas mean catchment slope is $52.9 \%$ and main stream slope is $7.8 \%$.

The area is considered highly important from a hydrological point of view as it is one of the rainiest areas of Greece territory [45], whereas extensive torrential phenomena (e.g., landslides, erosion) appeared due to the vulnerable geological subsoil (e.g., limestone and flysch) [46].

Moreover, the region has great environmental importance as it belongs to the European nature conservation network, Natura 2000, according to the criteria of Directive 92/43/EEC and is specifically included asa Site of Community Importance (SCI) with code GR1440002, namely: "Kerketio Oros (Koziakas)" [47]. The main habitat types encountered are the Hellenic beech forests with Abies borisii-regis (9270), thermophilous deciduous oak forests (91M0), Alpine and subalpine calcareous grassland (6170), Pteridium aquilinum stands (5150), and Calcareous rocky slopes with chasmophytic vegetation (8210). 


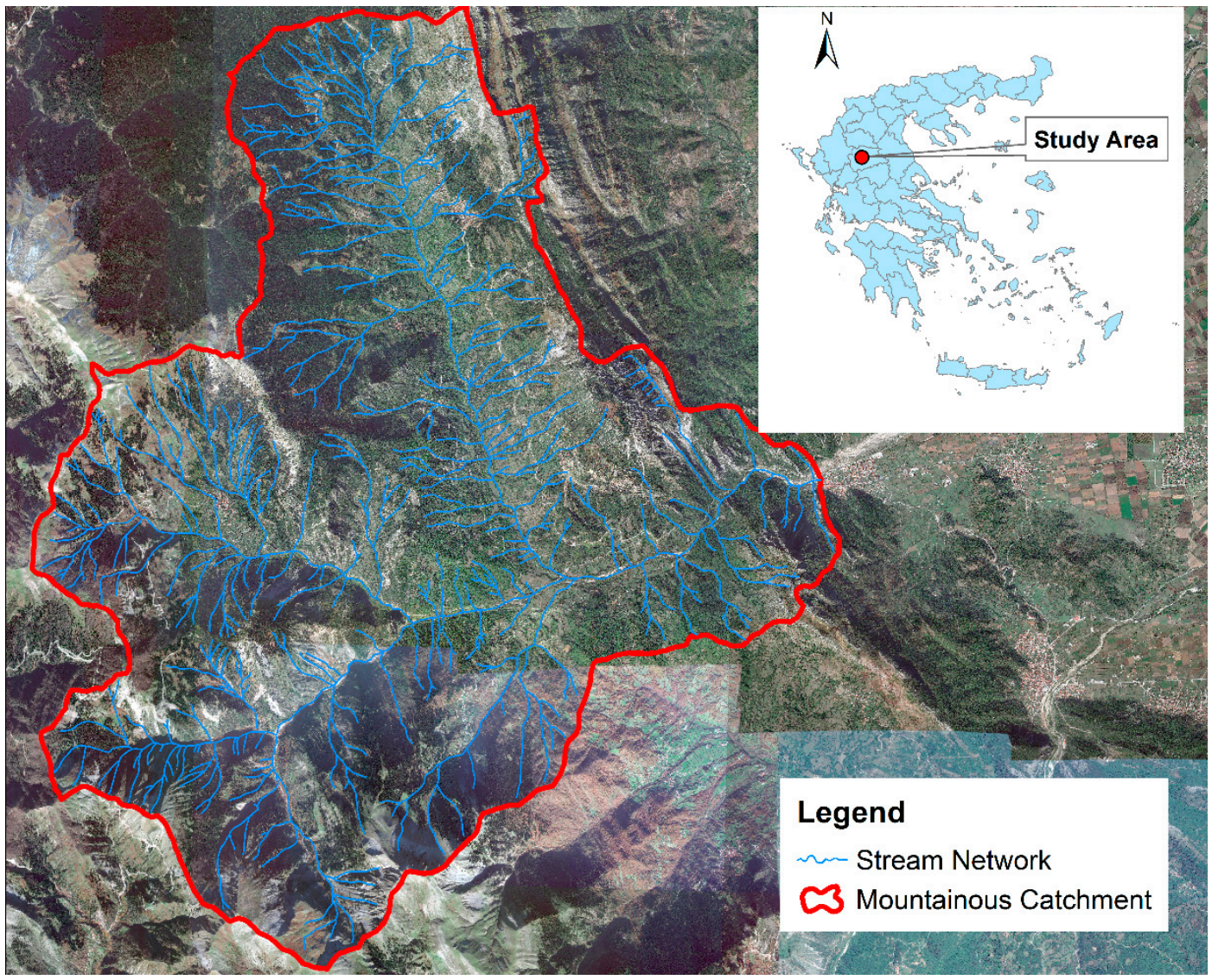

Figure 1. A map of the study area.

\subsection{Climate Simulation}

Currently, general circulation models (GCMs) are being widely used to estimate future projections in order to satisfy the growing interest in the impact of climate change on a global scale. GCMs are numerical models that simulate physical processes in the atmosphere, the ocean, the cryosphere, and the surface of the soil based on the laws of conservation of momentum, mass, total energy, and quantity of water vapor. The spatial analysis of GCMs gives satisfactory results for global circulation across the planet, as well as the general characteristics of various climatic parameters on a concise scale. However, it is not possible to precisely simulate phenomena related to the effect of topography on a local and regional scale due to local conditions and particularities, such as complex topography, coastlines, lakes, and small islands [48].

To this end, a number of statistical $[4,5]$ or dynamic $[49,50]$ downscaling techniques have been developed to bridge the gap between the large-scale GCM information and local scales. The statistical methods use the observed relationships between large-scale circulation and the local climate, whereas dynamic techniques use physically based regional climate models (RCMs).

In the frame of the EU funding project, ENSEMBLE (http://ensembles-eu.metoffice.com), a set of multi-model RCM simulations for characterizing climate change in Europe with high spatial resolution $(25 \times 25 \mathrm{~km})$, was produced. A recent study by Stefanidis [51] evaluated the ability of seven RCMs of the ENSEMBLE project under the A1B SRES emission scenario to represent temperature and precipitation conditions over the mountainous Central Pindus (the study area) for the baseline period 1974-2000. The results concluded that the best simulations were made by the International Centre for the Theoretical Physics Regional Climate Model (RegCM3) [52]. Therefore, in this study, regional climate analysis was performed using daily temperature and precipitation-simulated data derived from the RegCM3 model for the baseline period (1974-2000) and future period (2074-2100). 
Additionally, mean monthly precipitation and temperature simulations and observations were compared over the period of 1974-2000 (Figure 2). The observational data were derived by the nearest meteorological station in the study area (Pertouli) with available temperature and precipitation data.
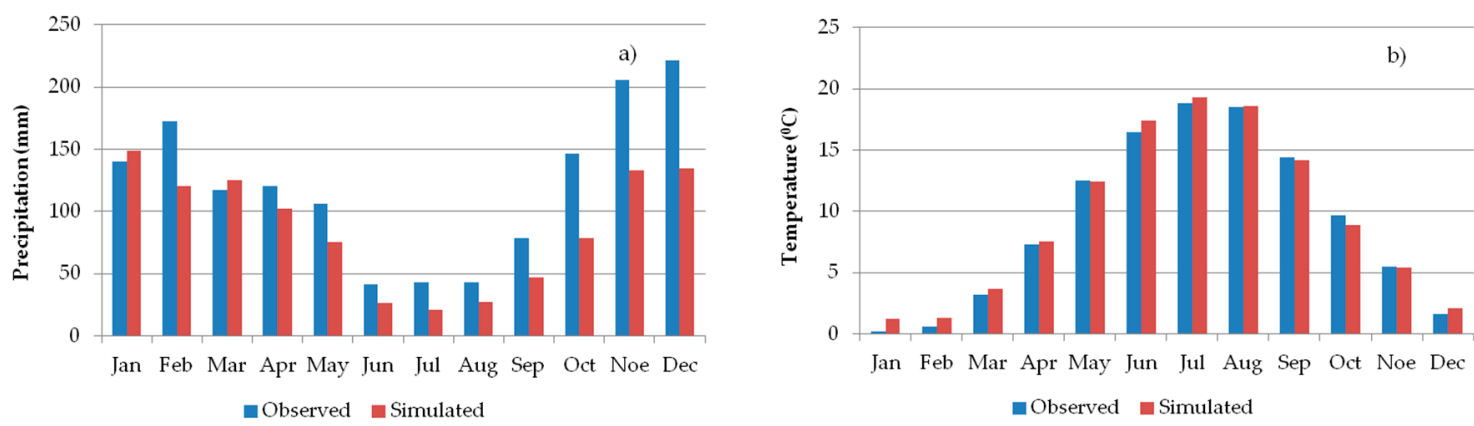

Figure 2. Comparison of (a) mean monthly precipitation $(\mathrm{mm})$ and $(\mathbf{b})$ mean monthly temperature $\left({ }^{\circ} \mathrm{C}\right)$ between observed (meteorological station) and simulated (RegCM3) data over the period of 1974-2000.

\subsection{Methodology}

In order to evaluate the performance of the RegCM3 model, observed values of precipitation and temperature from the meteorological station were compared with simulated values of the model over the baseline period 1974-2000. The Root Mean Square Error (RMSE) and Mean Bias Error (MBE) were used as evaluation indexes. The combination of these criteria has been widely used for the evaluation of RCMs $[4,53,54]$. The mathematical description of these indexes is given below $[55,56]$ :

$$
\begin{aligned}
\text { RMSE } & =\sqrt{\frac{1}{n} \sum_{i=1}^{n}\left(y_{i}-x_{i}\right)^{2}} \\
M B E & =\frac{1}{n} \sum_{i=1}^{n}\left(y_{i}-x_{i}\right)
\end{aligned}
$$

where $n$ is the number of observations, and $x_{i}$ and $y_{i}$ are the observed and simulated values, respectively, for $i=1,2, \ldots, n$. The RMSE gives the weighted variations (residuals) in errors between the simulated and observed values, while the $M B E$ measures the weighted average magnitude of the errors. $M B E$ is the most natural and unambiguous measure of average error magnitude $[57,58]$. RMSE, on the other hand, is one of the most widely used error measures. It is mentioned that the smaller the values of RMSE and MBE, the better the performance of the model.

The Erosion Potential Model (EPM) [31] was used in order to estimate annual soil loss. The mathematical description of the model is given in the following equation:

$$
W=T \times H \times \pi \times \sqrt[3]{Z} \times F
$$

where $W$ is the mean annual soil loss ( $\mathrm{m}^{3}$ /year), $H$ is the mean annual precipitation $(\mathrm{mm}), \pi$ is a mathematical constant approximately equal to $3.14159, F$ is the catchment area $\left(\mathrm{km}^{2}\right)$, and $T$ is a coefficient of temperature, given by the equation below:

$$
\sqrt{\frac{t_{0}}{10}+0.1}
$$

where $t_{0}$ is the average annual temperature $\left({ }^{\circ} \mathrm{C}\right)$ and $\mathrm{Z}$ is the coefficient of erosion, given by the next equation:

$$
\mathrm{Z}=x \times y(\varphi+\sqrt{J})
$$


where $x$ quantifies the protective nature of the land cover, $y$ is a coefficient expressing soil resistance to erosion, $\varphi$ quantifies the observed erosion process, and $J$ is the mean slope of the catchment (\%). The values' range of the above-mentioned coefficients $(x, y$, and $\varphi)$ are given in Table 1 .

Table 1. Descriptive variables used in the Erosion Potential Model (EPM).

\begin{tabular}{lc}
\hline Coefficient of Land Cover & $x$ \\
\hline Mixed and dense forest & $0.05-0.20$ \\
Thin forest with grove & $0.05-0.20$ \\
Coniferous forest with little grove, scarce bushes, bushy prairie & $0.20-0.40$ \\
Damaged forest and bushes, pasture & $0.40-0.60$ \\
Damaged pasture and cultivated land & $0.60-0.80$ \\
Areas without vegetal cover & $0.80-1.00$ \\
\hline Coefficient of soil erodibility & $y$ \\
\hline Hard rock, erosion resistant & $0.2-0.6$ \\
Rock with moderate erosion resistance & $0.6-1.0$ \\
Weak rock, schistose, stabilized & $1.0-1.3$ \\
Sediments, moraines, clay and other rock with little resistance & $1.3-1.8$ \\
Fine sediments and soils without erosion resistance & $1.8-2.0$ \\
\hline Coefficient of type and extent of erosion & $\boldsymbol{\varphi}$ \\
\hline Little erosion on catchment & $0.1-0.2$ \\
Erosion in waterways on 20 to $50 \%$ of the catchment area & $0.3-0.5$ \\
Erosion in rivers, gullies and alluvial deposits, karstic erosion & $0.6-0.7$ \\
50 to 80\% of catchment area affected by surface erosion and landslides & $0.8-0.9$ \\
Whole catchment affected by erosion & 1.0 \\
\hline
\end{tabular}

Aerial orthophotos maps, with a scale of 1:5000, were used in order to evaluate the land cover coefficient $(x)$. The coefficient of soil erodibility $(y)$ was determined from geological maps with a scale of 1:50,000 of the Institute of Geology and Mineral Exploration of Greece (IGME), and the coefficients of type and extent of erosion $(\varphi)$ were evaluated from field observations and recognition of sediment sourced areas and the state of erosion. Subsequently, the mean annual precipitation $(H)$ and the temperature coefficient $(T)$ were derived from the data of the RegCM3 model of ENSEMBLE. Finally, the mean catchment slope $(J)$ and catchment area $(F)$ were determined from a digital elevation model (DEM) with a cell size of $5 \times 5 \mathrm{~m}$.

\section{Results}

Firstly, the ability of the RegCM3 model to simulate the climate condition (precipitation and temperature) in the study area was evaluated using criteria of the RMSE and MBE. Results from the calculation of the RMSE and MBE between the simulated and observed precipitations (mm) during the period of 1974-2000 are given in the figure below (Figure 3). The model generally underestimated monthly precipitation in most cases except for January and March, where a slight overestimation can be observed. Also, it can be seen that better simulation was achieved in spring and summer.

Additionally, the above-mentioned evaluation criteria were calculated regarding temperature $\left({ }^{\circ} \mathrm{C}\right)$ data (Figure 4). It was found that the model overestimated mean monthly temperatures for almost all months, except for September and October. Moreover, as revealed from the analysis, better temperature simulation was achieved for winter and autumn. 

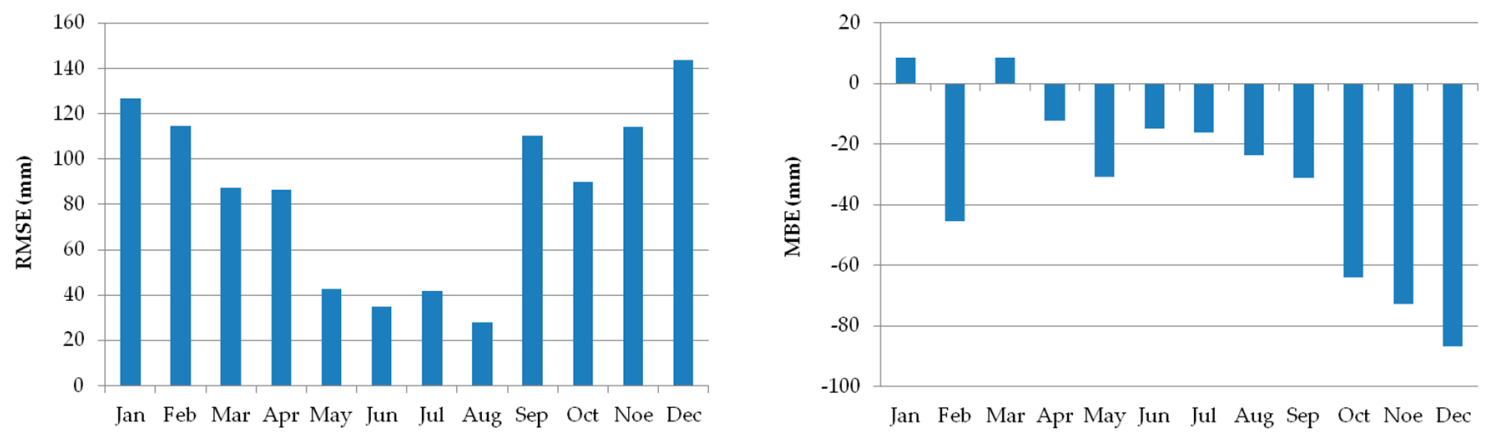

Figure 3. Root mean square error (RMSE) and mean bias error (MBE) values between simulated (RegCM3) and observed (meteorological station) precipitation data for the baseline period 1974-2000.

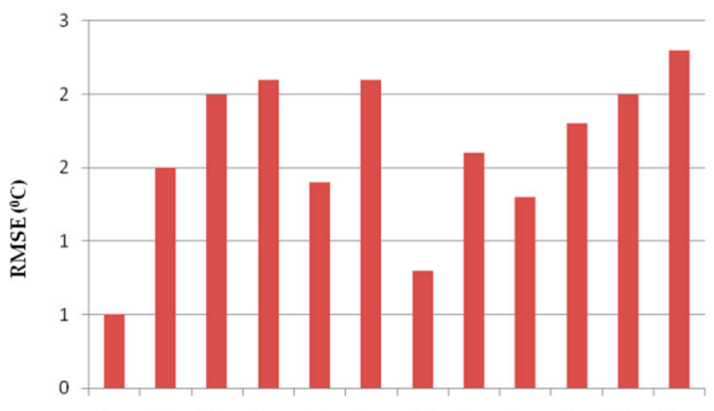

Jan Feb Mar Apr May Jun Jul Aug Sep Oct Noe Dec

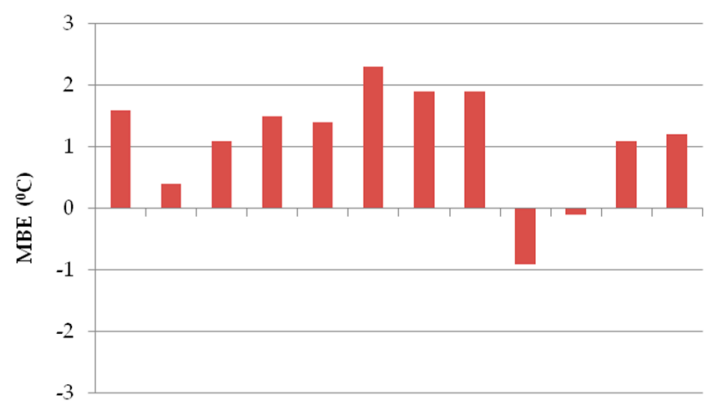

Jan Feb Mar Apr May Jun Jul Aug Sep Oct Noe Dec

Figure 4. RMSE and MBE values between simulated (RegCM3) and observed (meteorological station) temperature data for the baseline period 1974-2000.

Analysis of the land cover showed that dense forest cover was approximately $35.2 \%$ of the total catchment area, and thin forests were $24.7 \%$, agricultural crops $18 \%$, pastures $8.5 \%$, dense shrubs $4.9 \%$, scarce shrubs $3 \%$, barren land $4.6 \%$, and settlements $1.1 \%$. In order to determine the coefficient of land cover $(x)$, based on Table 1, the value 0.125 were was to the dense forest, 0.20 to thin forests, 0.25 to dense shrubs, 0.60 to scarce shrubs, 0.7 to pastures, 0.8 to agricultural crops, 0.9 to barren land, and 0 to settlements.

Regarding the geology of the study area, it was found that it mainly consisted of limestone $(47.2 \%)$ and flysch $(44.5 \%)$, followed by neogene rocks $(6.5 \%)$ and alluvial deposits $(1.8 \%)$. The following values of soil erodibility ( $y$ coefficient) were assigned to each petrographic formation: 0.8 to limestone, 1.15 to flysch, 1.55 to neogene rock, and 1.0 to alluvial deposits. The coefficients of land cover $(x)$ and soil erodibility $(y)$ were selected based on literature [33-36].

Also, following the field observations, the value 0.6 was given to the $\varphi$ coefficient. The catchment area (F coefficient) was found to be equal to $136.4 \mathrm{~km}^{2}$ after processing the DEM of the study area through GIS techniques $[9,46]$, and the slopes were found to be rather intense, ranging from $1.5 \%$ to $89.3 \%$. The land cover, geology, and slope (\%) maps are shown in the next figure (Figure 5). 

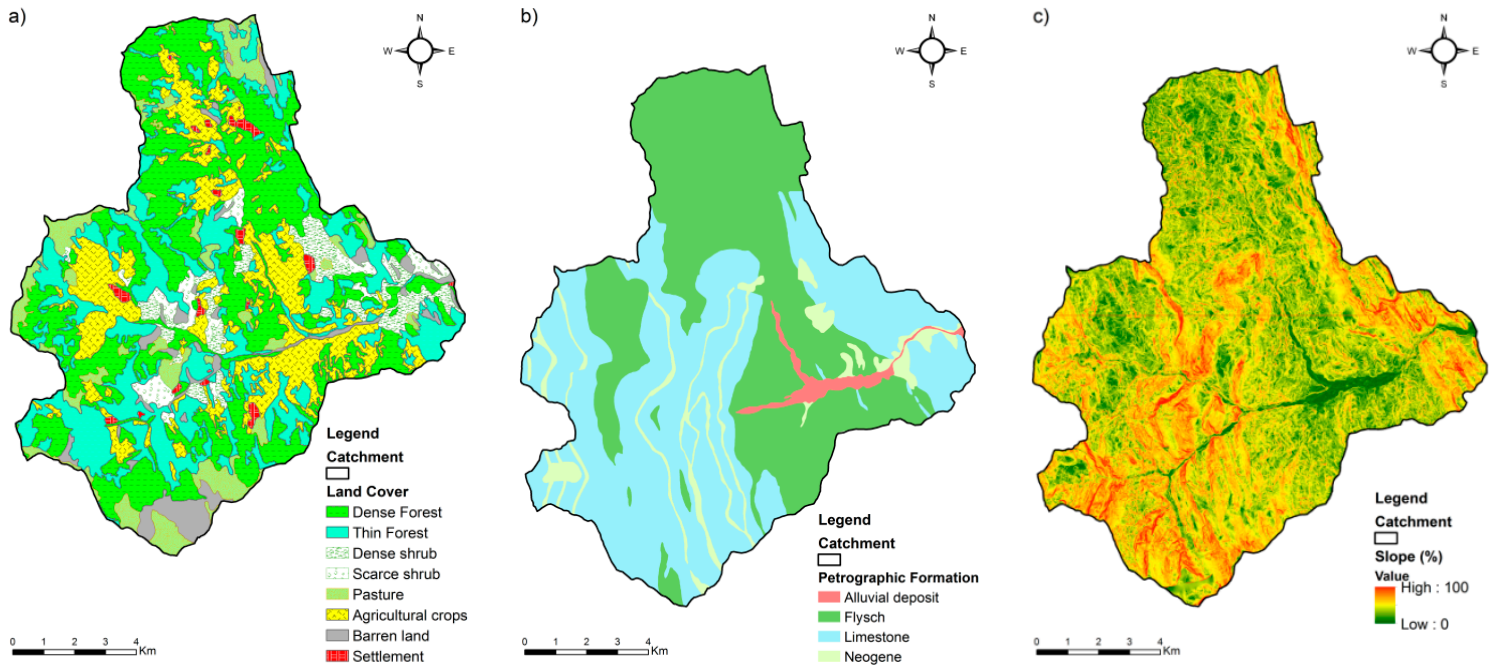

Figure 5. Spatial distribution of (a) land cover, (b) petrographic formation, and (c) slope (\%) within the study area.

The climate was evaluated from the precipitation $(\mathrm{mm})$ and temperature $\left({ }^{\circ} \mathrm{C}\right)$ time-series data of the RegCM3 model for the periods 1974-2000 and 2074-2100. The analysis highlighted a decrease $(-21.2 \%)$ in annual precipitation $(\mathrm{mm})$ and a significant increase $\left(+3.6^{\circ} \mathrm{C}\right)$ in mean annual temperature until the end of the 21st century (Figure 6). Specifically, the annual precipitation was expected to decrease from $1071.2 \mathrm{~mm}$ (1974-2000) to $874.1 \mathrm{~mm}$ (2074-2100) and the mean annual temperature was expected to increase from $9.3{ }^{\circ} \mathrm{C}$ to $13.0^{\circ} \mathrm{C}$. The biggest decrease in precipitation level will be in the months of spring and autumn, whereas the temperature increase will be greater in summer and winter.
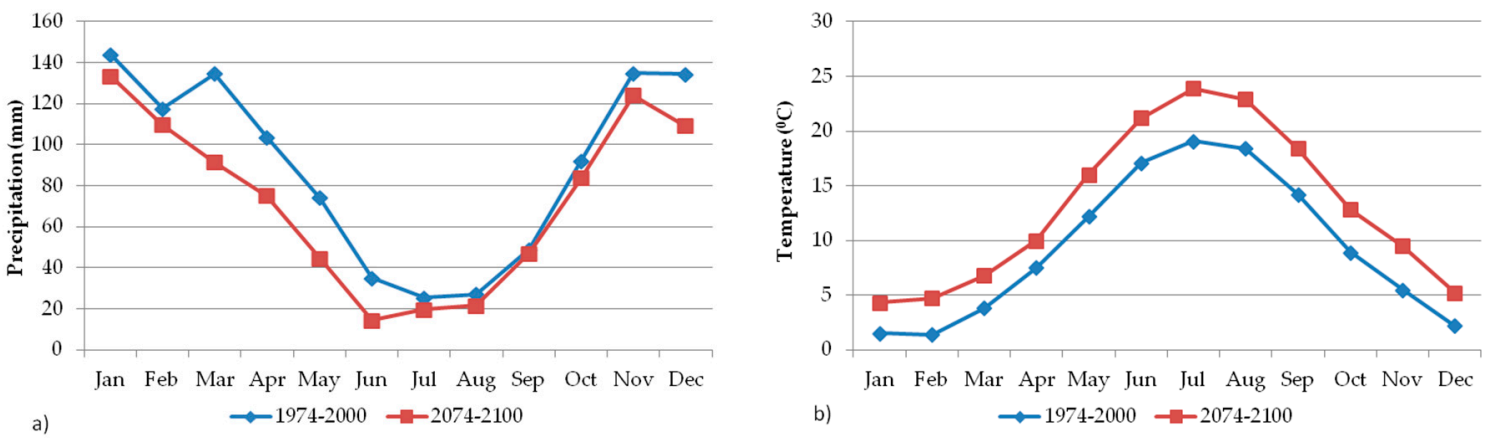

Figure 6. Comparison of (a) precipitation $(\mathrm{mm})$ and $(\mathbf{b})$ temperature $\left({ }^{\circ} \mathrm{C}\right)$ regimes in the study area, as revealed by the Theoretical Physics Regional Climate Model (RegCM3).

Using the above-mentioned parameter and EPM formula (Gavrilovič method), the soil loss $\left(\mathrm{m}^{3} /\right.$ year $)$ and catchment erosion rate $\left(\mathrm{m}^{3} /\right.$ year $\left./ \mathrm{km}^{2}\right)$ were estimated for the baseline (1974-2000) and future (2074-2100) period. Finally, the results were compared between them so as to quantify the effects of climate change on soil erosion. It was noticed that soil loss would decrease by $7920.5 \mathrm{~m}^{3}$ /year $(-4.9 \%)$ and, consequently, the erosion rate by $58.1 \mathrm{~m}^{3} /$ year $/ \mathrm{km}^{2}$. Detailed results can be seen in Table 2.

Table 2. Annual soil loss and erosion rate under present and future climate conditions.

\begin{tabular}{ccc}
\hline Period & Soil Loss $\left(\mathbf{m}^{\mathbf{3}} /\right.$ year $)$ & Erosion Rate $\left(\mathbf{m}^{3} /\right.$ year $\left./ \mathbf{k m}^{2}\right)$ \\
\hline $1974-2000$ & $161,236.5$ & 1182.1 \\
$2074-2100$ & 153316 & 1124 \\
\hline
\end{tabular}




\section{Discussion}

According to studies which compared the results of the EPM model with actual measurements, it was found that the model overestimated soil loss by 10\% [32-36]. The erosion rate in the study area was considered rather high in comparison with other areas of the Greek territory [59]. Despite the high forest cover, the vulnerable geological subsoil and the steep slopes were found to favor the development of erosion phenomena.

Nowadays, there is an urgent need for reliable future climate projections for rational catchment management and infrastructure project scheduling. The most modern tool used to simulate future climate conditions is the regional climate model (RCM). However, using models can introduce uncertainty in relation to a number of significant temporal and spatial scaling issues of the input data. Generally, RCMs underestimate monthly precipitation and overestimate temperature, whereas better simulation can be achieved in spring and summer for precipitation and winter and autumn for temperature data $[60,61]$.

Concerning future climate conditions in the Mediterranean region [60,61], and especially Greece [3,48,62-65], the climate is expected to be warmer and dryer. Additionally, the temperature in Central Europe is projected to increase between $+2{ }^{\circ} \mathrm{C}$ and $+5{ }^{\circ} \mathrm{C}$. Even though annual precipitation is projected to increase up to $+10 \%$, most RCMs project a significant decrease of precipitation in summer [66]. Moreover, extreme precipitations will be more frequent [5], as well as torrential flooding and debris-flow phenomena.

\section{Conclusions}

In this study, the effect of climate change on soil erosion in a mountainous catchment of Central Greece was assessed using the erosion prediction model of Gavrilovič and climate simulation of the RegCM3regional climate model. The main conclusions drawn are the following:

- Annual soil loss was found to be equal to $161,236.5 \mathrm{~m}^{3} /$ year, and the erosion rate $1182.1 \mathrm{~m}^{3} /$ year $/ \mathrm{km}^{2}$, by applying the Gavrilovič erosion prediction model (EPM) in the mountainous catchment of the Portaikos torrent.

- Concerning future climate conditions in the study area, based on RegCM3 data, a decrease $(-21.2 \%)$ in annual precipitation $(\mathrm{mm})$ and increase $\left(+3.6^{\circ} \mathrm{C}\right)$ in mean annual temperature is expected until the end of the 21st century. The above-mentioned model emphasized a greater decrease in monthly rainfall, especially in spring. As for the temperature, a greater increase in mean monthly temperature should occur in summer.

- Finally, considering the reported changes in climatic condition in the research area, a slight decrease $(-4.9 \%)$ in erosion rate was estimated. It is suggested that similar surveys should be done all over the Greek mountainous regions so as to identify future erosion-prone areas. Moreover, investigations of the effect of climate change on other hydrometeorological hazards (e.g., flash floods, landslides, etc.) is necessary for adaption and mitigation measures. The EURO-CORDEX project's comparison of the results of the current study with recent very high-resolution $(10 \times 10 \mathrm{~km})$ climate change projections [67] could be the target of future research in order to highlight the importance of using the finer-resolution model over complex terrain areas, such as Greece. Simulations of finer timescale data (e.g., daily) could also be examined.

Author Contributions: S.S. analyzed and processed the GIS data, applied the EMP model and wrote the paper, while D.S. analyzed the RCMs data and supervised the research.

Funding: This research received no external funding.

Acknowledgments: RegCM3 regional climate model data have been provided through the ENSEMBLES data archive (http:/ / ensembles-eu.metoffice.com/), funded by the European Commission (Contact Number GOCE-CT-2003-505539). The authors would like to express their gratitude to Konstantia Tolika and Theodoros Mavromatis for their constructive comments and guidance during the data processing.

Conflicts of Interest: The authors declare no conflict of interest. 


\section{References}

1. Intergovernmental Panel on Climate Change (IPCC). Climate Change 2013: The Physical Science Basis. Contribution of Working Group I to the Fifth Assessment Report of the Intergovernmental Panel on Climate Change; Cambridge University Press: Cambridge, UK, 2013.

2. Giorgi, F.; Lionello, P. Climate change projections for the Mediterranean region. Glob. Planet. Chang. 2008, 63, 90-104. [CrossRef]

3. Tolika, K.; Zanis, P.; Anagnostopoulou, C. Regional climate change scenarios for Greece: Future temperature and precipitation projections from ensembles of RCMs. Glob. NEST J. 2012, 14, 407-421.

4. Tolika, K.; Maheras, P.; Vafiadis, M.; Flocas, H.A.; Arseni-Papadimitriou, A. Simulation of seasonal precipitation and raindays over Greece: A statistical downscaling technique based on artificial neural networks (ANNs). Int. J. Climatol. J. R. Meteorol. Soc. 2007, 27, 861-881. [CrossRef]

5. Tolika, K.; Anagnostopoulou, C.; Maheras, P.; Vafiadis, M. Simulation of future changes in extreme rainfall and temperature conditions over the Greek area: A comparison of two statistical downscaling approaches. Glob. Planet. Chang. 2008, 63, 132-151. [CrossRef]

6. Nearing, M.A.; Pruski, F.F.; O'neal, M.R. Expected climate change impacts on soil erosion rates: A review. J. Soil Water Conserv. 2004, 59, 43-50.

7. Nastos, P.; Evelpidou, N.; Vassilopoulos, A. Does climatic change in precipitation drive erosion in Naxos Island, Greece? Nat. Hazards Earth Syst. Sci. 2010, 10, 379-382. [CrossRef]

8. Plangoen, P.; Babel, M.S.; Clemente, R.S.; Shrestha, S.; Tripathi, N.K. Simulating the impact of future land use and climate change on soil erosion and deposition in the Mae Nam Nan sub-catchment, Thailand. Sustainability 2013, 5, 3244-3274. [CrossRef]

9. Stefanidis, S.; Chatzichristaki, C. Response of soil erosion in a mountainous watershed to temperature and precipitation trends. Carpath. J. Earth Environ. Sci. 2017, 12, 35-39.

10. EC. Proposal for a Establishing a Framework for the Protection of Soil and Amending. Directive 2004/35/EC COM, 232. 2006. Available online: https://eur-lex.europa.eu/legal-content/EN/TXT/?uri= celex:52006PC0232 (accessed on 25 September 2018).

11. Panagos, P.; Borrelli, P.; Poesen, J.; Ballabio, C.; Lugato, E.; Meusburger, K.; Montanarella, L.; Alewell, C. The new assessment of soil loss by water erosion in Europe. Environ. Sci. Policy 2015, 54, 438-447. [CrossRef]

12. Maheras, P.; Anagnostopoulou, C. Circulation types and their influence on the interannual variability and precipitation changes in Greece. In Mediterranean Climate; Springer: Berlin, Germany, 2003; pp. 215-239.

13. García-Orenes, F.; Roldán, A.; Mataix-Solera, J.; Cerdà, A.; Campoy, M.; Arcenegui, V.; Caravaca, F. Soil structural stability and erosion rates influenced by agricultural management practices in a semi-arid Mediterranean agro-ecosystem. Soil Use Manag. 2012, 28, 571-579. [CrossRef]

14. Kairis, O.; Karavitis, C.; Salvati, L.; Kounalaki, A.; Kosmas, K. Exploring the impact of overgrazing on soil erosion and land degradation in a dry Mediterranean agro-forest landscape (Crete, Greece). Arid Land Res. Manag. 2015, 29, 360-374. [CrossRef]

15. Nicu, I.C. Is Overgrazing Really Influencing Soil Erosion? Water 2018, 10, 1077. [CrossRef]

16. Fernández, C.; Vega, J.A.; Vieira, D.C.S. Assessing soil erosion after fire and rehabilitation treatments in NW Spain: Performance of RUSLE and revised Morgan-Morgan-Finney models. Land Degrad. Dev. 2010, 21, 58-67. [CrossRef]

17. Myronidis, D.I.; Emmanouloudis, D.A.; Mitsopoulos, I.A.; Riggos, E.E. Soil erosion potential after fire and rehabilitation treatments in Greece. Environ. Model. Assess. 2010, 15, 239-250. [CrossRef]

18. Myronidis, D.; Ioannou, K.; Sapountzis, M.; Fotakis, D. Development of a sustainable plan to combat erosion for an island of the Mediterranean region. Fresenius Environ. Bull. 2010, 19, 1694-1702.

19. Pradeep, G.S.; Krishnan, M.N.; Vijith, H. Identification of critical soil erosion prone areas and annual average soil loss in an upland agricultural watershed of Western Ghats, using analytical hierarchy process (AHP) and RUSLE techniques. Arab. J. Geosci. 2015, 8, 3697-3711. [CrossRef]

20. Khanday, M.Y.; Javed, A. Prioritization of sub-watersheds for conservation measures in a semi-arid watershed using remote sensing and GIS. J. Geol. Soc. India 2016, 88, 185-196. [CrossRef]

21. Romero-Díaz, A.; Cammeraat, L.H.; Vacca, A.; Kosmas, C. Soil erosion at three experimental sites in the Mediterranean. Earth Surf. Process. Landf. J. Br. Geomorphol. Res. Group 1999, 24, 1243-1256. [CrossRef] 
22. Stefanidis, P.; Sapountzis, M.; Stathis, D. Sheet erosion after fire at the urban forest of Thessaloniki (Northern Greece). Silva Balc. 2002, 2, 65-77.

23. Boix-Fayos, C.; Martínez-Mena, M.; Arnau-Rosalén, E.; Calvo-Cases, A.; Castillo, V.; Albaladejo, J. Measuring soil erosion by field plots: Understanding the sources of variation. Earth-Sci. Rev. 2006, 78, 267-285. [CrossRef]

24. Cerdan, O.; Govers, G.; Le Bissonnais, Y.; Van Oost, K.; Poesen, J.; Saby, N.; Gobin, A.; Vacca, A.; Quinton, J.; Auerswald, K.; et al. Rates and spatial variations of soil erosion in Europe: A study based on erosion plot data. Geomorphology 2010, 122, 167-177. [CrossRef]

25. Kosmadakis, I.; Tsardaklis, P.; Ioannou, K.; Zaimes, G.N. A Novel Fully Automated Soil Erosion Monitoring System. In Proceedings of the 7th International Conference on Information and Communication Technologies in Agriculture, Food and Environment (HAICTA 2015), Kavala, Greece, 17-20 September 2015; pp. 80-84.

26. Karydas, C.G.; Panagos, P.; Gitas, I.Z. A classification of water erosion models according to their geospatial characteristics. Int. J. Digit. Earth 2014, 7, 229-250. [CrossRef]

27. Wischmeier, W.H.; Smith, D.D. Predicting Rainfall Erosion Losses, a Guide to Conservation Planning; U.S. Department of Agriculture: Washington, DC, USA, 1978; Volume 537, p. 62.

28. Renard, K.G.; Foster, G.R.; Weesies, G.A.; Porter, J.P. RUSLE: Revised universal soil loss equation. J. Soil Water Conserv. 1991, 46, 30-33.

29. Morgan, R.P.C. A simple approach to soil loss prediction: A revised Morgan-Morgan-Finney model. Catena 2001, 44, 305-322. [CrossRef]

30. Nearing, M.A.; Foster, G.R.; Lane, L.J.; Finkner, S.C. A process-based soil erosion model for USDA-Water Erosion Prediction Project technology. Trans. ASAE 1989, 32, 1587-1593. [CrossRef]

31. Gavrilovič, S. Engineering of Debris Flow and Erosion; Izgradnja: Beograd, Serbia, 1972; p. 292. (In Serbian)

32. De Vente, J.; Poesen, J. Predicting soil erosion and sediment yield at the basin scale: Scale issue and semi-quantitative models. Earth Sci. Rev. 2005, 71, 95-125. [CrossRef]

33. Sapountzis, M.; Myronidis, D.; Stathis, D.; Stefanidis, P. Comparison of the predicted erosion rates by USLE and GAVRILOVIC methods with field measurements. In Proceedings of the 1st Joint Conference EYE-EEDYP, Volos, Greece, 27-30 May 2009; pp. 155-165. (In Greek)

34. Xanthakis, M. Soil Erosion Study in Mountainous Basins with Modern Technological Tools. Ph.D. Thesis, Harokopio University of Athens, Athens, Greece, 2011. (In Greek)

35. Anastasiou, S. Determination of Degradation and Sediment Sources in Torrents' Watersheds of Serres, Using GIS. Master's Thesis, Aristotle University of Thessaloniki, Thessaloniki, Greece, 2013. (In Greek)

36. Efthimiou, N.; Lykoudi, E.; Panagoulia, D.; Karavitis, C. Assessment of soil susceptibility to erosion using the EPM and RUSLE models: The case of Venetikos River Catchment. Glob. NEST J. 2016, 18, 164-179.

37. Simonneaux, V.; Cheggour, A.; Deschamps, C.; Mouillot, F.; Cerdan, O.; Le Bissonnais, Y. Land use and climate change effects on soil erosion in a semi-arid mountainous watershed (High Atlas, Morocco). J. Arid Environ. 2015, 122, 64-75. [CrossRef]

38. Teng, H.; Liang, Z.; Chen, S.; Liu, Y.; Rossel, R.A.V.; Chappell, A.; Yu, W.; Shi, Z. Current and future assessments of soil erosion by water on the Tibetan Plateau based on RUSLE and CMIP5 climate models. Sci. Total Environ. 2018, 635, 673-686. [CrossRef] [PubMed]

39. Anagnostopoulos, G.G.; Koutsoyiannis, D.; Christofides, A.; Efstratiadis, A.; Mamassis, N. A comparison of local and aggregated climate model outputs with observed data. Hydrol. Sci. J. 2010, 55, 1094-1110. [CrossRef]

40. Koutsoyiannis, D.; Efstratiadis, A.; Georgakakos, K.P. Uncertainty assessment of future hydroclimatic predictions: A comparison of probabilistic and scenario-based approaches. J. Hydrometeorol. 2007, 8, 261-281. [CrossRef]

41. Koutsoyiannis, D.; Efstratiadis, A.; Mamassis, N.; Christofides, A. On the credibility of climate predictions. Hydrol. Sci. J. 2008, 53, 671-684. [CrossRef]

42. Anagnostopoulou, C.; Tolika, K.; Maheras, P.; Reiser, H.; Kutiel, H. Quantifying uncertainties in precipitation: A case study from Greece. Adv. Geosci. 2008, 16, 19-26. [CrossRef]

43. Nalbantis, I.; Efstratiadis, A.; Rozos, E.; Kopsiafti, M.; Koutsoyiannis, D. Holistic versus monomeric strategies for hydrological modelling of human-modified hydrosystems. Hydrol. Earth Syst. Sci. 2011, 15, 743-758. [CrossRef] 
44. Serpa, D.; Nunes, J.P.; Santos, J.; Sampaio, E.; Jacinto, R.; Veiga, S.; Lima, J.C.; Moreira, M.; Corte-Real, J.; Keizer, J.J.; et al. Impacts of climate and land use changes on the hydrological and erosion processes of two contrasting Mediterranean catchments. Sci. Total Environ. 2015, 538, 64-77. [CrossRef] [PubMed]

45. Stathis, D.; Myronidis, D. Principal component analysis of precipitation in Thessaly region (Central Greece). Glob. NEST J. 2009, 11, 467-476.

46. Tziaftani, F. The Causes and Mechanism of the Landslides Phenomena in Mountainous Watersheds of Torrents in Greece. Watershed Management and Torrent Control Systems. Ph.D. Thesis, Aristotle University of Thessaloniki, Thessaloniki, Greece, 18 February 2013. (In Greek)

47. Tsitsoni, T.; Zagas, T.; Ganatsas, P. Plant diversity and Nature Conservation in Koziakas Natura 2000 (Network) Site, Central Greece. In Proceedings of the 6st International Conference «Protection and Restoration of the Environment VI», Skiathos, Greece, 1-5 July 2002; Volume 1, pp. 609-616.

48. Zanis, P.; Katragkou, E.; Ntogras, C.; Marougianni, G.; Tsikerdekis, A.; Feidas, H.; Anadranistakis, E.; Melas, D. Transient high-resolution regional climate simulation for Greece over the period 1960-2100: Evaluation and future projections. Clim. Res. 2015, 64, 123-140. [CrossRef]

49. Rummukainen, M. State-of-the-art with Regional Climate Models. Wiley Interdiscip. Rev. Clim. Chang. 2010, 1, 82-96. [CrossRef]

50. Xue, Y.; Janjic, Z.; Dudhia, J.; Vasic, R.; De Sales, F. A review on regional dynamical downscaling in intraseasonal to seasonal simulation/prediction and major factors that affect downscaling ability. Atmos. Res. 2014, 147, 68-85. [CrossRef]

51. Stefanidis, S. Hydronomy of Mountainous Catchments under Climate Change in Central Pindus. Ph.D. Thesis, Aristotle University of Thessaloniki, Thessaloniki, Greece, 2018. (In Greek)

52. Jacob, D.; Bärring, L.; Christensen, O.B.; Christensen, J.H.; de Castro, M.; Déqué, M.; Giorgi, F.; Hagemann, S.; Hirschi, M.; Jones, R.; et al. An inter-comparison of regional climate models for Europe: Model performance in present-day climate. Clim. Chang. 2007, 81, 31-52. [CrossRef]

53. Rockel, B.; Geyer, B. The performance of the regional climate model CLM in different climate regions, based on the example of precipitation. Meteorol. Z. 2008, 17, 487-498. [CrossRef]

54. Teutschbein, C.; Seibert, J. Bias correction of regional climate model simulations for hydrological climate-change impact studies: Review and evaluation of different methods. J. Hydrol. 2012, 456, 12-29. [CrossRef]

55. Hyndman, R.J.; Koehler, A.B. Another look at measures of forecast accuracy. Int. J. Forecast. 2006, 22, $679-688$. [CrossRef]

56. Willmott, C.J.; Matsuura, K. On the use of dimensioned measures of error to evaluate the performance of spatial interpolators. Int. J. Geogr. Inf. Sci. 2006, 20, 89-102. [CrossRef]

57. Willmott, C.J.; Matsuura, K. Advantages of the mean absolute error (MAE) over the root mean square error (RMSE) in assessing average model performance. Clim. Res. 2005, 30, 79-82. [CrossRef]

58. Chai, T.; Draxler, R. Root mean square error (RMSE) or mean absolute error (MAE)?-Arguments against avoiding RMSE in the literature. Geosci. Model Dev. 2014, 7, 1247-1250. [CrossRef]

59. Kazamias, A.P.; Sapountzis, M. Spatial and temporal assessment of potential soil erosion over Greece. Water 2017, 59, 315-321.

60. Gallardo, C.; Arribas, A.; Prego, J.A.; Gaertner, M.A.; De Castro, M. Multi-year simulations using a regional-climate model over the Iberian Peninsula: Current climate and doubled $\mathrm{CO}_{2}$ scenario. Q. J. R. Meteorol. Soc. 2001, 127, 1659-1681. [CrossRef]

61. Bergant, K.; Belda, M.; Halenka, T. Systematic errors in the simulation of European climate (1961-2000) with RegCM3 driven by NCEP/NCAR reanalysis. Int. J. Climatol. 2007, 27, 455-472. [CrossRef]

62. Paparrizos, S.; Maris, F.; Matzarakis, A. Integrated analysis of present and future responses of precipitation over selected Greek areas with different climate conditions. Atmos. Res. 2016, 169, 199-208. [CrossRef]

63. Theodossiou, N. Assessing the Impacts of Climate Change on the Sustainability of Groundwater Aquifers. Application in Moudania Aquifer in N. Greece. Environ. Process. 2016, 3, 1045-1061. [CrossRef]

64. Koufos, G.C.; Mavromatis, T.; Koundouras, S.; Jones, G.V. Response of viticulture-related climatic indices and zoning to historical and future climate conditions in Greece. Int. J. Climatol. 2018, 38, 2097-2111. [CrossRef]

65. Lazoglou, G.; Anagnostopoulou, C.; Koundouras, S. Climate change projections for Greek viticulture as simulated by a regional climate model. Theor. Appl. Climatol. 2018, 133, 551-567. [CrossRef] 
66. Kling, H.; Fuchs, M.; Paulin, M. Runoff conditions in the upper Danube basin under an ensemble of climate change scenarios. J. Hydrol. 2012, 424, 264-277. [CrossRef]

67. Tolika, K.; Anagnostopoulou, C.; Velikou, K.; Vagenas, C. A comparison of the updated very high resolution model RegCM3_10km with the previous version RegCM3_25km over the complex terrain of Greece: Present and future projections. Theor. Appl. Climatol. 2016, 126, 715-726. [CrossRef] 